\title{
Volunteer Income Tax Assistance (VITA) Program Dramatically Increases Knowledge Retention And Student Skills
}

\author{
John Balden (E-mail: john@balden.com), Utah Valley State College, Orem \\ Michael Stemkoski (E-mail: stemkomi@uvsc.edu), Utah Valley State College, Orem \\ Melinda A. Bender (E-mail: benderme@uvsc.edu), Utah Valley State College, Orem \\ Henderson S. Allen (E-mail: sam@travata.com), Utah Valley State College, Orem
}

\begin{abstract}
In academia, faculty have the challenge of developing programs that will instill in the students the core competencies and skills defined by the accounting profession as the benchmark for successful entry into the accounting profession by college graduates. By integrating participation in the Volunteer Income Tax Assistance program with the teaching of concepts in the classroom at Utah Valley State College, faculty have been able to increase the retention of knowledge and the development of practical skills that benefit students, potential employers, and the community.
\end{abstract}

\subsection{Introduction}

n many disciplines, dialogue continues among academicians to determine the best practices, techniques, and strategies to use in the classroom to achieve desired student competencies. For the accounting profession, the American Institute of Certified Public Accountants (AICPA) has established the desired core competencies for accounting graduates with its Core Competency Framework for Entry Into the Accounting Profession. Information regarding the framework is summarized on the Website http://www.aicpa.org/edu/corecomp.htm (American Institute of Certified Public Accountants, 2002). The framework project provides a list of strategies and teaching methodologies that may be used to teach the technical content of accounting courses and addresses the development of one or more of the core competencies. Two of the teaching strategies listed, problem-based learning through cases and service learning through fieldwork, can be accomplished through the applied learning methodology of integrating the Volunteer Income Tax Assistance (VITA) program with the accounting curriculum.

In 1999, an AICPA education task force of the Tax Education Committee updated and modified its recommendations for a model tax curriculum originally prepared in 1996. The task force firmly believed that certain skills development should be part of the process of imparting tax knowledge. The committee stated that in a rapidly changing environment successful students need these skills: communication and leadership, strategic and critical thinking, technological competency, and business and professional ethical awareness (American Institute of Certified Public Accountants, 2001). Involvement of tax students in the VITA program has been an integral part of helping the students develop these skills.

Applied learning is a methodology often cited as an instructor's tool to help students integrate course concepts into real world situations in the effort to achieve desired competencies. Students generally learn most effectively when they can see, touch, and do, not just sit at a desk and listen (Kohn, 1993, p. 211). Applied learning has been praised for placing the student at the center of the leaning process. Practitioners have accepted applied learning as a means of developing the necessary interdisciplinary core competencies and knowledge retention for accounting students (Kohn, 1993, p. 219). Placing students in a situation of being able to make mistakes offers

Readers with comments or questions are encouraged to contact the authors via email. 
information about how a student thinks. It has been established in academic circles that applied reality based learning is one of the learning components to achieving student competencies (Kohn, 1993, p. 212).

The integration of the Volunteer Income Tax Assistance (VITA) program with the curriculum of the classroom is a model that combines real world application of the tax law and service to the community with learning in an academic environment. By placing students in a real world situation through preparing tax returns for individuals and small business taxpayers from the community, students practice and experience what they are learning in their tax courses. Students increase their functional, personal, and broad business perspective (broadbased) competencies as a result of applying what they learn. Participation in the VITA program allows "student practitioners" to be paired with taxpayers. The students are placed in a situation where they have to react to real facts and circumstances that affect real people. This situation gives students the opportunity to interview clients; identify tax issues; draw upon their tax knowledge; research publications, regulations, and tax code provisions; evaluate and recommend different tax strategies; and synthesize all of this into responding to the needs of the taxpayer (Dunlevy, 2002).

\subsection{Brief History of VITA Programs}

The IRS has sponsored the VITA program for over 30 years, and colleges and universities have used the program to let students prepare income tax returns. Certain college-sponsored sites either integrate the VITA program directly into the federal income tax courses or include it as a professional activity sponsored by a student organization such as an accounting club, or as a service-learning project through the campus Service-Learning Center. All student participants receive training or mentoring for the VITA program in order to be eligible to prepare returns. There are various programs ranging from small community colleges to the University of Chicago Law School, Duke University School of Law, New York University, and Michigan State University where students from many disciplines may participate in preparing tax returns by enrolling at the Service-Learning Center (Michigan State University, 2001).

For example, SUNY Fredonia located outside of Buffalo, New York, has been assisting taxpayers for over twenty years. The Fredonia program serves elderly, low-income, and non-English speaking taxpayers in the Northern Chautauqua County community, and the program provides assistance in the form of free tax return preparation and answering tax related questions (Olsavsky, 2001).

Other student programs are more recent, such as the VITA operations at Montgomery County Community College's West Campus and St. Joseph's University in Philadelphia. These programs provide a learning experience for their students and a service to the community. At St. Joseph's University, the students are not required to be in an accounting or business curriculum. A team approach is used where more experienced and enrolled "student tax practitioners" are teamed with students from other disciplines. As a Jesuit university, St. Joseph's encourages service as a part of its mission "to mold leaders committed to service, adept at solving problems, and active in the improvement of the social order" (Dunlevy, 2002). The VITA program at St. Joseph's University helps students from all disciplines to fulfill these aspirations. The learning experience is interdisciplinary and team based.

California State College, Northridge was, in 1971, the first university sponsored VITA program. In 2002, students at CSUN prepared more than 16,000 state and federal returns. Each year, more than 250 CSUN students go through a training program for the university's VITA program volunteers. Because of the demand, eligibility has to be limited to those taxpayers with a gross annual income of not more than $\$ 40,000$. CSUN has assisted colleges across the country in establishing their own programs (California State, Northridge, 2002).

The best way to begin a program is by researching various programs over the Web, contacting the IRS, and working with the local IRS representative. For example, by searching with the key words "Volunteer Income Tax Assistance" on the Web, there are more relevant lists of Websites provided than searching VITA. Various helpful sites such as the site http://www.uni.edu/schmidt/vita/ at the University of Northern Iowa are available to explain the Volunteer Income Tax Assistance program. A list of steps to organize a successful VITA site can be found online at 
http://www.mdcc.edu/wolfson/departments/business/vita.htm for the VITA program at Miami-Dade Community College's Wolfson Campus.

\subsection{The VITA Program at UVSC}

The initial involvement of students in the VITA program at Utah Valley State College (UVSC) began at a time when the college had only a two-year associate degree program. The program has expanded into a major annual undertaking involving the students of a growing bachelor's degree program. During the initial years, different faculty directed the VITA program with limited success. The program was run casually until 1995; then the decision was made to give students an expanded opportunity to participate in a real world experience and contribute to the community with their tax knowledge. After considering programs that had been operating at other colleges, the faculty at UVSC developed their own program. Since the initial effort in 1995, the Volunteer Income Tax Assistance program at Utah Valley State College has become one of the largest programs of its kind in the United States. The IRS has recognized this program for its outstanding achievements.

Due to continued growth, the program requires increasing amounts of time and personnel to manage and administer the program. During the 2001-2002 filing season, the VITA program requirements became the main activity for the site coordinator. This faculty member maintained a full-time teaching load. Under ideal circumstances when the budgetary sources are available, a faculty member should receive released time to administer the program. As an alternative, outside funding can compensate a site coordinator to administer the program. Even with current constraints of time and personnel, UVSC's VITA program has continued to grow. The following table (Table 1) shows the statistical history of the program over the last five filing seasons.

Table 1: Volunteer Income Tax Assistance: Utah Valley State College - VITA Site 84058

Summary of Annual Statistics

\begin{tabular}{|c|c|c|c|c|c|c|}
\hline & Tax Return Year & 2001 & 2000 & 1999 & 1998 & 1997 \\
\hline Number of Volunteers & & 152 & 148 & 124 & 109 & 98 \\
\hline Total Volunteer Hours worked & & 2574 & 1654 & 1507 & 966 & 908 \\
\hline Number of Taxpayers Assisted & & 4353 & 3332 & 2394 & 1930 & 1527 \\
\hline Individual Federal Returns Prepared & & 2577 & 1983 & 1562 & 1294 & 1015 \\
\hline Married Filing Joint Federal Returns Prepared & & 1462 & 1014 & 742 & 583 & 498 \\
\hline Federal Returns Filed Electronically & & 2179 & 1311 & 1461 & 571 & 451 \\
\hline Manually Prepared Returns & & 0 & 0 & 0 & 0 & 0 \\
\hline State \& Local Returns Prepared & & 4241 & 3147 & 2336 & 1979 & 1532 \\
\hline Other Assistance to Taxpayers & & 314 & 334 & 109 & 53 & 14 \\
\hline
\end{tabular}


For the 2001-2002 filing season, the VITA program at UVSC had one faculty coordinator, a CPA with 22 years of tax experience, and five part-time student assistants who helped prepare returns and answer questions. One of the student assistants was in charge of coordinating electronic filing. Over 150 volunteers participated in the program. The majority were students from the tax classes. Other volunteers were former students who returned to volunteer after they had completed the tax courses and graduated from the college. The faculty site coordinator volunteered over 700 potentially billable work hours during and after the tax season. The other volunteers contributed over 1800 potentially billable hours. Assuming the tax manager (faculty coordinator) could be billed out at $\$ 200.00$ per billable hour and other volunteers could be billed at $\$ 100.00$ per hour, the UVSC VITA program contributed over $\$ 300,000.00$ to the community this past year.

A chronological breakdown analysis of the work performed during the year is included in the following table (Table 2).

Table 2: Volunteer Income Tax Assistance Worksheet Summary - Utah Valley State College

\begin{tabular}{|c|c|c|c|c|c|c|c|c|c|c|}
\hline Reporting Period & Volunteers & $\begin{array}{c}\text { Hours } \\
\text { Worked }\end{array}$ & $\begin{array}{c}\text { Taxpayers } \\
\text { Assisted }\end{array}$ & Individual & Joint & E-File & States & EITC & $\begin{array}{l}\text { Child } \\
\text { Credit }\end{array}$ & Other \\
\hline January 1-5, 2002 & 1 & 0.25 & 1 & 1 & 0 & 0 & 1 & 1 & 0 & 0 \\
\hline January 6-12, 2002 & 1 & 0.33 & 1 & 0 & 0 & 2 & 15 & 3 & 0 & 1 \\
\hline January 13-19, 2002 & 4 & 5.58 & 5 & 4 & 1 & 2 & 21 & 6 & 1 & 0 \\
\hline January 20-26, 2002 & 7 & 12.67 & 15 & 13 & 2 & 16 & 42 & 9 & 3 & 0 \\
\hline Jan 27-Feb 2, 2002 & 70 & 148.65 & 256 & 141 & 102 & 32 & 243 & 49 & 90 & 13 \\
\hline February 3-9, 2002 & 85 & 253.77 & 425 & 237 & 168 & 246 & 427 & 70 & 98 & 20 \\
\hline February 10-16, 2002 & 89 & 251.23 & 403 & 224 & 159 & 218 & 396 & 61 & 95 & 20 \\
\hline February 17-23, 2002 & 95 & 232.32 & 344 & 198 & 136 & 314 & 343 & 53 & 83 & 10 \\
\hline February 24-March 2, 2002 & 84 & 219.83 & 342 & 219 & 111 & 236 & 333 & 58 & 65 & 12 \\
\hline March 3-9, 2002 & 91 & 231.17 & 351 & 230 & 100 & 177 & 340 & 48 & 52 & 21 \\
\hline March 10-16, 2002 & 97 & 227.87 & 352 & 211 & 123 & 159 & 353 & 26 & 57 & 18 \\
\hline March 17-23, 2002 & 90 & 202.47 & 327 & 203 & 101 & 167 & 325 & 42 & 35 & 23 \\
\hline Mar 24-30, 2002 & 44 & 76.30 & 117 & 73 & 35 & 70 & 110 & 7 & 13 & 9 \\
\hline March 31-April 6, 2002 & 92 & 262.27 & 405 & 229 & 125 & 177 & 368 & 59 & 62 & 51 \\
\hline April 7-13, 2002 & 99 & 318.93 & 551 & 386 & 124 & 242 & 542 & 52 & 74 & 41 \\
\hline April 14-20, 2002 & 53 & 100.85 & 374 & 185 & 161 & 96 & 346 & 26 & 14 & 28 \\
\hline April 21-27, 2002 & 8 & 15.50 & 29 & 12 & 5 & 14 & 17 & 2 & 5 & 12 \\
\hline Apr 28-May 4, 2002 & 1 & 3.33 & 22 & 5 & 4 & 3 & 9 & 0 & 0 & 13 \\
\hline May 5-11, 2002 & 1 & 4.00 & 17 & 3 & 3 & 1 & 6 & 0 & 0 & 11 \\
\hline May 12-18, 2002 & 1 & 4.50 & 9 & 0 & 2 & 3 & 2 & 0 & 1 & 7 \\
\hline May 19-31, 2002 & 2 & 4.33 & 22 & 3 & 0 & 4 & 2 & 0 & 0 & 19 \\
\hline June 1-30, 2002 & 3 & 5.33 & 12 & 4 & 0 & 3 & 5 & 0 & 0 & 8 \\
\hline July $1-31,2002$ & 1 & 4.33 & 20 & 1 & 0 & 0 & 1 & 0 & 0 & 19 \\
\hline August 1-31, 2002 & 2 & 4.83 & 24 & 4 & 0 & 3 & 4 & 0 & 0 & 20 \\
\hline Totals & 152 & $2,590.65$ & 4424 & 2586 & 1462 & 2185 & 4251 & 572 & 748 & 376 \\
\hline
\end{tabular}




\subsection{How the VITA Program Functions at UVSC}

In the VITA program at Utah Valley State College, students enter the taxpayer's information into a personal computer program to prepare the tax returns to be filed with the IRS and state taxing authorities. They also answer tax related questions and perform simple tax planning.

Taxpayers start seeking help with preparation of their tax returns as early as the first week of January. Since the number of taxpayers at this time of the year is small, and volunteers are just beginning their training, the VITA services in early January are generally provided by appointment. When the program begins at the end of January, there are designated days (on a first-come, first-served basis) when students are available to process tax returns for taxpayers.

Computer labs are available in the Business Building for students to use in preparing tax returns. At the available times, taxpayers line up as they arrive outside the designated lab. Three computer labs, with a total of 75 computers, are available for students to process tax returns. The majority of the returns are processed on Fridays or Saturdays throughout the tax season during designated lab times. The volunteers can prepare tax returns at other times and days when they find open computers in the labs. Taxpayers come to the site from the community. Most of the taxpayers are students attending UVSC; some taxpayers are referred to the site by the local IRS tax office, and others hear of the VITA program from friends.

Every student who takes a tax class during the tax season is required to process five live tax returns. Many students do more than five returns. For example, during the 2001-2002 filing season, there were 23 students who prepared over 50 returns each. In the beginning, many students are often reluctant to participate. After interviewing and preparing returns for three to five taxpayers, the students usually overcome their fears and insecurities and become excited about helping taxpayers file their returns.

When a taxpayer comes to the VITA site during the open lab times, they are assigned to a student who interviews and gathers the needed information to prepare the return. Most commonly, students input the information from W-2 forms and process the returns immediately for mailing or electronic filing. For more complicated returns, students may interview the taxpayer, gather the necessary information, and then conduct additional research before the return can be completed. In other cases, the taxpayer will be asked to collect more information before the tax return is finished. This is often the case with small business returns or more complicated returns. Students do not perform bookkeeping tasks for the taxpayers. The taxpayers are asked to arrive with their tax information organized. Students have a checklist of what is needed in order to complete a simple return. Taxpayers who come to the site for the second or third year are usually prepared, and the tax return can be completed in one short session.

Many student volunteers bring taxpayer information to the site from family and friends and prepare the returns as they have time. Faculty members allow the students to prepare any return they feel comfortable preparing. The student assistants help students process the tax returns and review forms for completeness. The program coordinator reviews any return at the request of the student or the taxpayer. If a return is filed electronically, the faculty coordinator must also review the return before it is sent to the IRS.

The taxpayer is not charged for the tax return preparation when the taxpayer elects to mail the return. Since the VITA program at UVSC incurs additional time and cost in processing the electronically filed returns, a $\$ 10$ contribution is requested from taxpayers who choose to have their returns filed electronically. The taxpayer benefits from the electronic filing by receiving their refund much faster. The program continues to receive voluntary payments on almost $80 \%$ of the electronically filed returns. These funds received from electronic filing help pay the wages of assistants, help cover the cost of the software used to prepare and file the returns, and help purchase miscellaneous expenses such as toner, paper, and envelopes. 


\subsection{Benefits to Students and Faculty}

Students enrolled in tax classes during the filing season receive credit in the tax courses for participating in the VITA program. During the filing season, students cannot receive an A grade in the course unless they prepare live tax returns. Additionally, the college recently instituted a Service-Learning Distinction Program that honors students involved in service learning at graduation. They receive a distinctive cord, marching at commencement with College Honors students, a distinction on their transcript, a certificate of achievement, and acknowledgement at commencement and a banquet. The VITA program qualifies as one of the Service-Learning programs on campus that a student may participate in order to meet the Service-Learning Distinction requirements.

Students have a wide range of client experiences while participating in the VITA program. The program gives UVSC students a real world experience that mimics the client/service provider relationship in industry and accounting firms. By gaining this exposure to real world situations, students can make better decisions concerning their careers. Students may find after participating in the VITA program that they do not want to pursue a career in tax accounting. Other students may find interest in pursuing the tax path in graduate school.

In addition to the invaluable tax preparation experience that students receive, they are often exposed to unusual real world circumstances. For example, one student had a client interview interrupted by the local county sheriff's deputy who wanted to take the taxpayer to jail on an outstanding warrant. This student insisted that the taxpayer first be allowed to sign the electronic filing forms for the return before the client could be taken. The deputy relented, and the return was filed although the client was concerned with where his tax refund would be sent.

\subsection{Administrative Analysis of the UVSC VITA Program}

The benefits of the program have been numerous. Based on the experiential research of the VITA program, the students have performed and competed in graduate programs and in private industry at a higher level than before the program was instituted. The program has increased the prestige of the college among hiring entities. VITA has also increased grant opportunities and voluntary contributions. It provides valuable service to local individuals and small businesses. Occasionally students obtain short-term or long-term job opportunities as a result of their contacts in the VITA program. In the final analysis, the students increase their functional, personal, and broad-based perspective competencies. This has increased recruiting for both employment and graduate school programs in taxation as well as helping the students understand the value of service in the community.

There are several improvements that can be implemented into the UVSC program. Various programs have used practitioners from accounting practices to periodically attend tax preparation sessions to observe students and to give students their (practitioner's) feedback. This simple mentoring exercise enhances the students' knowledge and understanding of what is expected in the workplace.

With the volume of volunteers and taxpayers and the limited number of supervisory personnel, it is difficult to maintain high product quality. The site coordinator sometimes spends a good deal of time correcting or amending returns prepared by students who did not ask enough questions or seek help when a difficult issue presented itself. The risk of preparing a return at a VITA site is similar to the risk of getting a hair cut. Most of the mistakes can be smoothed over or fixed with the passing of time. The student who is involved in repairing such a mistake is not likely to make the same mistake again. Knowledge retention increases dramatically for the student and others who are involved in fixing the problem.

The most uncomfortable challenge in implementing the integration of the VITA program with the curriculum has been meeting the costs involved. The faculty members sought funding through college budgets, asking for voluntary donations to cover costs, and charging for services beyond the preparation of the return. With increasing demands on the college budget dollars, expecting the institution to fund the program will work when the program is small. As the program grows, seeking funding from outside sources may become necessary. The first year that the UVSC program suggested a voluntary contribution from the taxpayer, VITA barely received enough to cover software costs and supplies for printing the returns. The most successful method of financing the program has 
been to request a voluntary payment for the additional service of electronic filing. This part of the service involves the most non-visible time requirements. Sending the returns, retrieving the acknowledgements, and processing rejections are labor intensive.

To foster the development of programs that assist taxpayers in disadvantaged groups, the Internal Revenue Service also provides a grant opportunity. The IRS provides awards of up to $\$ 100,000$ of matching funds to qualifying programs each year. This award can be received a total of three times. Last year, the IRS awarded a total of $\$ 7$ million. The Website at http://www.unclefed.com/Tax-News/2002/nr02-03.html contains information on the recipients receiving tax clinic grants.

\subsection{Analysis of Student Retention Rates for Tax Skills and Knowledge}

Participation in the VITA program is one of the best practices for achieving the AICPA competencies for tax accounting students in their first tax course. The learned competencies result from placing the student at the center of learning in a real world environment. The students are placed in a position to stretch and think about what they are doing for someone else in a real life situation. It is suggested that students' retention of information follows identifiable patterns. The knowledge retention patterns seem to reflect "The Cone of Learning," developed and revised by researchers Bruce Hyland and Edgar Dale (1969). The research demonstrates students tend to remember:

- $\quad 10 \%$ of what they read (textbook).

- $\quad 20 \%$ of what they hear (lectures).

- $\quad 30 \%$ of what they see (charts, power points, and transparencies).

- $\quad 50 \%$ of what they hear and see (video and movies).

- $\quad 70 \%$ of what they demonstrate and write (participating).

- $\quad 90 \%$ of what they do (real world practice--becoming aware of what they know and do not know).

An important component of the VITA experience is the students' development of solutions to problems that emerge during the tax preparation process. In the book, Thinking for a Living: Education and the Wealth of Nations, Marshal and Tucker (1992) define the skills to power an economy. These skills include

- $\quad$ An increased capacity for abstract conceptual thinking.

- $\quad$ The ability to apply the capacity for abstract thought to complex, real-world problems.

- $\quad$ The capacity to function effectively in an environment in which communication skills are vital in working with others.

Applying learning to real world problems creates an active learning environment that is necessary in powering an economy (Marshall \& Tucker, 1992). The cognitive activity does not exist independent of actioncentered skills. The melding of the analytical skills learned in the classroom with the application of those skills has the possibility of developing a student's conceptual thinking (Zuboff, 1984). The VITA program gives students the opportunity to reason out certain cues in the process of preparing a real tax return for a taxpayer.

\subsection{Conclusion}

The Utah Valley State College tax assistance program began as a community service program. It has evolved into an invaluable teaching resource. Students seem to retain more of the tax knowledge they are taught in class if they are able to immediately apply that knowledge in a real world experience. This paper recommends that one methodology to achieve the competencies is one of applied learning. Competencies have a higher possibility of being achieved through programs such as the Volunteer Income Tax Assistance program. The effects of the program have been dramatic, and the return on investment to the students easily justifies the time and cost invested in the program. As a result, the potential of the VITA program and other similar programs ought to gain greater appreciation among professional educators who want to help their students succeed. 
Involving the students in the Volunteer Income Tax Assistance (VITA) program at Utah Valley State College has helped the students achieve a higher level of knowledge and skill retention from their tax courses than from a traditional classroom alone. The program enables students to apply and internalize the skills they learn in their classes through the preparation of income tax returns for individuals and small businesses from the community. The faculty and employers have found that by combining normal academic tax classes with the preparation of tax returns for clients increases the students' depth and retention of tax knowledge. Students develop communication skills (client interviewing, follow-up questions), gain self-confidence (after about three returns, students overcome insecurities), have real life experiences, and develop realistic work habits. The students' interaction with the faculty site coordinator simulates the partner/manager/assistant relationship in industry and accounting firms. The mentoring process allows faculty and students to stay current in their field and complements the teaching focus through enhancement of instructional efforts and applied scholarship. The public service provides a social benefit to a diverse group of taxpayers in the community.

The faculty have found that a successful VITA program requires a dedicated faculty site coordinator, trained student assistants, capable volunteers, user-friendly tax preparation software, sufficient available computers, physical facilities for client meetings and return preparation, careful time management, and enough operating funds to pay the expenses.

\section{References}

1. American Institute of Certified Public Accountants. (2001). Model tax curriculum. Retrieved September 9, 2002, from http://www.aicpa.org/members/div/career/edu/introduce.htm

2. American Institute of Certified Public Accountants. (2002). Functional competencies. Retrieved September 9, 2002, from http://www.aicpa.org/edu/justedu.htm

3. California State, Northridge. (2002). CSU Northridge provides free tax help available to low income people. Retrieved September 3, 2002, from http://www.calstate.edu/newsline/Archive/01-02/020306-Nor.shtml

4. Callahan, Patrick J. (2000). UMass students offer free tax preparation service. Retrieved September 9, 2002, from http://www.umass.edu/newsoffice/archive/2000/032900taxes.html

5. Dale, Edgar. (1969). Audio-visual methods in teaching. ( $3^{\text {rd }}$ ed.). New York: Holt.

6. Dertouszos, M.L. et al. (1989). Made in America: Regaining the productive edge.

7. Cambridge: MIT

8. Dunlevy, Robert J. \& Sherman, W. Richard. (2002). Vita: A means to compete for the future.

9. [Electronic version]. Pennsylvania CPA Journal, 70 (4), 16.

10. Fred, John. (n.d.). Volunteer Income Tax Assistance. Retrieved September 9, 2002, from

11. http://www.law.duke.edu/student/act/vita.html

12. IRS tax news. (2002). IRS awards \$7million to tax clinics aiding low-income taxpayers. Retrieved September 9, 2002, from http://www.unclefed.com/Tax-News/2002/nr02-03.html

13. Kaplan, Jane E., \& Welker, Michael G. (2001). Team learning is here to stay.

14. New Accountant, 16(3), 15-16.

15. Kohn, Alfie. (1993). Punished by rewards. Boston: Houghton.

16. Miami-Dade's Wolfson Campus. (n.d.). Steps to organize a successful VITA center. Retrieved September 6, 2002, from http://www.mdcc.edu/wolfson/departments/business/vita.htm

17. Marshall, R., \& Tucker, M. (1992). Thinking for a living: Education and the wealth of nations. New York: Harper.

18. Michigan State University, Service-Learning Center. (2001). Volunteer income tax assistance. Retrieved September 9, 2002, from http://www.csp.msu.edu/slc/programs/vi01-02.htm

19. Olsavsky, John. (2001). Tax assistance through VITA program. Retrieved September 9. 2002, from http://www.fredonia.edu/prweb/releases/VITA.htm

20. Regent University. (2000). Catalog, School of Law. Retrieved September 9, 2002, from http://www.regent.edu/catalog2001/law/extracurr.html

21. Schmidt. (2002). VITA: Volunteer Income Tax Assistance. Retrieved September 9, 2002, from http://www.uni.edu/schmidt/vita/

22. Schuler, Peter. (1995). University of Chicago Law School ABA's public interest school of the year. Retrieved September 9, 2002, from http://www-news.uchicago.edu/releases/95/951207.law.school.rank.shtml

23. Zuboff, Shoshana. (1984). In the age of the smart machine: The future of work and power. New York: Basic Books. 